$1-1-2017$

\title{
Principle and Politics in the New History of Originalism
}

Logan E. Sawyer III

Associate Professor of Law University of Georgia, lesawyer@uga.edu

University of Georgia School of Law

Research Paper Series

Paper No. 2017-18

p Thepress SSRN

\section{Repository Citation}

Logan E. Sawyer III, Principle and Politics in the New History of Originalism , 57 Am. J. Legal Hist. 198 (2017),

Available at: https://digitalcommons.law.uga.edu/fac_artchop/1326

This Article is brought to you for free and open access by the Faculty Scholarship at Digital Commons @ University of Georgia School of Law. It has been accepted for inclusion in Scholarly Works by an authorized administrator of Digital Commons @ University of Georgia School of Law. Please share how you have benefited from this access For more information, please contact tstriepe@uga.edu. 


\title{
UNIVERSITY OF GEORGIA SCHOOL OF LAW
}

RESEARCH PAPER SERIES

Paper No. 2017-18

May 2017

\section{Principle AND Politics in the NeW HISTORY OF ORIGINALISM}

AM. J . LEGAL. HIST. (forthcoming).

\author{
LOGAN E. SAWYER III \\ Associate Professor of Law \\ University of Georgia School of Law \\ lesawyer@uga.edu
}

This paper can be downloaded without charge from the

Social Science Research Network electronic library at

https://ssm.com/abstract $=2933746$ 


\section{PRINCIPLE AND POLITICS in The New History of Originalism}

The emergence of a new form of originalism has sparked an interest in the theory's past that is particularly welcome as developments on the Supreme Court and in the Republican Party unsettle the theory's place in American law and politics. Our understanding of the theory's development, however, has been limited by an unfortunate and unnecessary division between what are now two separate histories of originalism. One history examines the theory's development in academia and emphasizes the influence of principled argument. A second investigates its role in politics and highlights the role of conservative interests. This review essay identifies this division and offers two ways to create a productive dialogue. It first suggests we consider how political interests have shaped the academic debates over originalism by influencing the institutions that produce those debates. Second, it urges a reconsideration of how and why academic debates have shaped the theory's political uses. There is good reason to consider whether principled constitutional argument, and thus the debates of academics, have shaped the political uses of originalism even if the theory's most important advocates were motivated mostly - or even entirely - by the pursuit of political advantage. Using these approaches to identify the reciprocal influence of politics and principle on originalism's past can help produce the new history of originalism we need to understand, evaluate, and influence the theory's role in American law and politics.

\section{Introduction}

We have gone from too few histories of originalism to too many, just when understanding the theory's past is needed to help address its suddenly uncertain future. For decades, originalism played an important and stable role in American law and politics: it was the constitutional theory of conservatives. ${ }^{1}$ Today, it is still embraced by conservative judges, academics, and 'tea party' revolutionaries, but its influence now extends to leading progressive academics and judges like Jack Balkin and Justice Kagan. ${ }^{2}$ Yet there are also indications the theory's influence may be starting

1 JonAthan O’NeILl, ORIGINALISM IN AMERICAN LAW AND POLITICS: A CONSTITUTIONAL HistORY (2005) [hereinafter O’NeILL, CONSTITUTIONAL HistORY]; Robert Post \& Reva Siegel, Originalism as Political Practice: The Right's Living Constitution, 75 FORDHAM L. REV. 545 (2006).

${ }^{2}$ Post \& Siegel, supra note 1; Christopher Schmidt, Popular Constitutionalism on the Right: Some Lessons from the Tea Party, 88 DENV. U. L. REV. 523 (2011); JACK M. 
to wane, including the death of Justice Scalia—originalism's most visible and perhaps most effective proponent-as well as disarray in the Republican Party. ${ }^{3}$

We understand these developments better because of a recent and growing interest in originalism's past, but the insight that literature offers has been limited by an unfortunate and unnecessary division. Right now, there are two separate histories of originalism. One examines originalism in the academy and emphasizes the way principled argument has shaped the theory's development. ${ }^{4}$ A second has investigated originalism's political history. It highlights how the theory has responded to conservative political interests. ${ }^{5}$

This essay provides a critical review of that literature that both calls attention to this division and suggests a way to bridge it. It does not try to critique or improve the practice of originalism itself. ${ }^{6}$ It is agnostic on the

BALKIN, LIVING ORIGINALISM (2011); The Nomination of Elena Kagan to be an Associate Justice of the Supreme Court of the United States: Hearing before the S. Comm. on the Judiciary, 111th Cong. 62 (2010) (testimony of Elena Kagan) (The founders "sometimes...laid down very specific rules. Sometimes they laid down broad principles. Either way we apply what they say, what they meant to do. So in that sense, we are all originalists.").

${ }^{3}$ Eric Posner, Why Originalism will Fade, ERICPOSNER.COM (February 18, 2016), http://ericposner.com/why-originalism-will-fade/. But see Jack Balkin, Why Originalism Will Not Fade Away, BALKINIZATION (February 19, 2016), http://balkin.blogspot.com/2016/02/why-originalism-will-not-fade-away.html [hereinafter Balkin, BALKINIZATION].

4 See, e.g., KeIth WhitTington, Constitutional Interpretation: TeXtual MEANING, ORIGINAL INTENT, AND JUdICIAL REVIEW (1999) [hereinafter WhitTINGTON, CONSTITUTIONAL InTERPRETATION]; Robert J. Delahunty \& John Yoo, Saving Originalism, 113 MiCH. L. REV. 1081 (2015) (reviewing AKHIL REED AMAR, AMERICA’s UNWRITTEN Constitution: The Precedents And Principles We LiVe By (2012)); Lawrence B. Solum, Originalism and the Unwritten Constitution, 2013 U. ILL. L. REV. 1935 [hereinafter Solum, Unwritten]; Keith E. Whittington, The New Originalism, 2 GEO. J.L. \& PuB. POL'y 599 (2004) [hereinafter Whittington, New Originalism]; Randy E. Barnett, An Originalism for Nonoriginalists, 45 LOY. L. REV. 611 (1999) [hereinafter Barnett, Nonoriginalists].

${ }^{5}$ See, e.g., Post \& Siegel, supra note 1; Mary Ziegler, Originalism Talk: A Legal History, 2014 BYU L. REV. 869 [hereinafter Ziegler, Originalism Talk]; Dawn E. Johnsen, Lessons from the Right: Progressive Constitutionalism for the Twenty-First Century, 1 HARV. L. \& POL’Y REV. 239 (2007) [hereinafter Johnsen, Lessons from the Right].

6 It is not, for example, an intervention into the ongoing debates over whether the methods of intellectual history should inform the practice of originalism. Lawrence B. Solum, Intellectual History as Constitutional Theory, 101 VA. L. REV. 1111 (2015) [hereinafter Solum, Intellectual History]; G. Edward White, Intellectual History and Constitutional Decision Making, 101 VA. L. REV. 1165 (2015) [hereinafter White, Intellectual History]; Jonathan Gienapp, Historicism and Holism: Failures of Originalist Translation, 84 FORDHAM L. REV. 935 (2015); Saul Cornell, Meaning and Understanding in the History of Constitutional Ideas: The Intellectual History Alternative to Originalism, 
proper originalist method and the propriety of originalism as a method of constitutional interpretation. It instead aims to improve our understanding of the theory as a historical phenomenon of importance to American law and politics by creating a productive dialogue between originalism's academic and political histories. Its core claim is that we can create that dialogue by building on insights produced by the recent investigations of the conservative legal movement and by applying traditional, but too easily forgotten, insights of intellectual history.

The emerging history of the conservative legal movement has shown how political interests helped create institutions like the Federalist Society and the law and economics movement, which have, in turn, had lasting effects on constitutional debate. ${ }^{7}$ Investigating similar links between originalism and conservative interests can help connect originalism's academic and political histories. Originalism's two histories can also be brought into dialogue by re-considering whether the conservative activists who use originalism in political debate have been constrained by boundaries of legitimate legal argument, and thus by debates of academics, which help establish those boundaries. Earlier efforts to explore this influence have been undermined by understandable doubts that political activists regularly place constitutional principle ahead of political interest. Thus, a primary goal of this review essay is to offer a plausible account of how the limits of principled argument might constrain the choices of political activists not in spite of the political motivations of those activists but instead because of those political motivations. ${ }^{8}$

A productive dialogue between originalism's political and academic histories can help create a new history of originalism that is more than an extension of the normative debates that have been underway for decades. The current divided history of originalism implicitly debates whether originalism has been a principled interpretive method or a mere rationalization for conservatism. But that question is far too simple to

82 FoRDHAM L. REV. 721 (2013) [hereinafter Cornell, Intellectual History]. See generally Symposium, The New Originalism in Constitutional Law, 82 FORDHAM L. REV. 371 (2013).

${ }^{7}$ See, e.g., AMANDA Hollis-Bruskey, IDEAS WiTH CONSEQUENCES: THE FEDERALIST SOCIETY AND THE CONSERVATIVE COUNTERREVOLUTION 20-21 (2015); STEVEN M. TELES, The Rise of the Conservative Legal Movement: The Battle for Control of the LAW (2008) (hereinafter TELES, RisE Of THE CONSERVATIVE LEGAL MOVEMENT).

8 See MEANING In CONTEXT: QuENTIN SKInNER AND HIS CRITICS 76 (James Tully ed., 1988); James T. Kloppenberg, Thinking Historically: A Manifesto of Pragmatic Hermeneutics, 9 MOD. INTELL. HIST. 201 (2012) [hereinafter Kloppenberg, Thinking Historically]. Explorations of other aspects of this approach include Cornell, Intellectual History, supra note 6, and Gienapp, Historicism and Holism, supra note 6. 
produce the insights we need to understand the theory's past and guide its future.

\section{Originalism's Two Histories}

The growing interest in understanding originalism's past is certainly welcome. Whether one finds originalism a convincing theory of constitutional interpretation or not, it has played a central role in American law and politics for decades. ${ }^{9}$ Studies of its development can help us evaluate the remarkable changes that have characterized the theory's recent past, as well as provide insights into American political development and the role constitutional theory plays in law and politics more generally. ${ }^{10}$ Unfortunately, the potential of this new interest has been limited by a division between work on originalism's development in academic debate and in political fora.

\section{Originalism's Principled Past}

Scholars became interested in originalism's past about a decade ago, ${ }^{11}$ but the history they have produced has proceeded along two different tracks, each of which has examined originalism in different contexts, has been driven by different concerns, and has provided different explanations for the theory's changes over time. One camp is largely populated by the advocates of what is now called the 'New Originalism.' With important support from the work of Jonathan O'Neill, ${ }^{12}$ Keith Whittington, Lawrence Solum, Randy Barnett, and others have turned to originalism's past in order to distinguish their arguments for 'New Originalism' - which focuses on the original public meaning of the constitution—from 'Old Originalism'—an interpretive method that emphasizes the intentions of the constitution's

\footnotetext{
9 See, e.g., O’Neill, CONSTItUtional History, supra note 1; Reva B. Siegel, Constitutional Culture, Social Movement Conflict, and Constitutional Change: The Case of the De Facto ERA, 94 CALIF. L. REV. 1323 (2006) [hereinafter Siegel, De Facto ERA].

10 See Jamal Greene, How Constitutional Theory Matters, 72 OHIO ST. L.J. 1183 (2011) [hereinafter Greene, How Constitutional Theory Matters]; Johnsen, Lessons from the Right, supra note 5.

${ }^{11}$ See O’Neill, Constitutional History, supra, note 1; Reva B. Siegel, Dead or Alive: Originalism as Popular Constitutionalism in Heller, 122 HARV. L. REV. 191 (2008) [hereinafter Siegel, Dead or Alive]; Jonathan O’Neill, Shaping Modern Constitutional Theory: Bickel and Bork Confront the Warren Court, 65 REV. OF PoL. 325 (2003) [hereinafter O’Neill, Bickel and Bork]; Jonathan O’Neill, Raoul Berger and the Restoration of Originalism, 96 Nw. U. L. REV. 253 (2001) [hereinafter O’Neill, Raoul Berger].

${ }^{12}$ See, e.g., O’NEILL, CONSTITUTIONAL HistORY, supra note 1.
} 
framers. ${ }^{13}$ As a result, they have developed an account of originalism's past that uses law reviews as core sources and that emphasizes the ways that principled argument has shaped the theory's development. ${ }^{14}$

In their account of originalism, the theory emerged when the Warren and Burger Courts' aggressive protection of individual rights alarmed scholars concerned with judicial restraint, ${ }^{15}$ popular sovereignty, ${ }^{16}$ or separation of powers, republican government, and the rule of law. ${ }^{17}$ Convinced these values were not being protected by political process jurisprudence or calls for judicial restraint, Raoul Berger, Robert Bork, and others refocused constitutional interpretation on the original intentions of Constitution's drafters. ${ }^{18}$ Like the critics of the 'Lochner Court' whose mantle they adopted, these scholars were concerned primarily with majority rule and democratic legitimacy. ${ }^{19}$ The focus of the 'Old Originalism' they developed was the subjective intent of the founders, ${ }^{20}$ which was used to limit judicial discretion ${ }^{21}$ and to criticize the Warren and Burger Courts. They did not, however, produce a comprehensive theory of constitutional interpretation. $^{22}$

Scholars began to abandon this Old Originalism in response to academic challenges, intellectual developments, and changes in at the

13 Jamal Greene, The Case for Original Intent, 80 GEO. WASH. L. REV. 1683 (2012) [hereinafter Greene, Original Intent] (arguing that the goal of this history was to differentiate old and new originalism).

${ }^{14}$ See Whittington, Constitutional InTERPRetation, supra note 4; Delahunty \& Yoo, supra note 4; Jack M. Balkin, The New Originalism and the Uses of History, 82 FordHAM L. REV. 641 (2013) [hereinafter Balkin, New Originalism]; Solum, Unwritten, supra note 4; Barnett, Nonoriginalists, supra note 4, at 611-12; Lawrence B. Solum, District of Columbia v. Heller and Originalism, 103 Nw. U. L. REV. 923, 927 (2009) [hereinafter Solum, Heller]; Whittington, New Originalism, supra note 14; Michael W. McConnell, The Role of Democratic Politics in Transforming Moral Convictions into Law, 98 YALE L.J. 1501, 1525 (1989) (reviewing MiCHAEL J. PERRY, MORALITY, POLITICS AND LAW (1988); Earl Maltz, Foreword: The Appeal of Originalism, 1987 UTAH L. REV. 773, 779-95; see also Greene, Original Intent, supra note 13, at 1687 n.23 (calling Barnett's description of the shift from original intent to original meaning the "standard account").

15 See Whittington, New Originalism, supra note 14, at 601-02 ("Above all, originalism was a way of explaining what the Court had done wrong, and what it had done wrong in this context was primarily to strike down government actions in the name of individual rights.”).

${ }^{16}$ Solum, Heller, supra note 14 , at 930.

${ }^{17}$ O’NEILL, CONSTITUTIONAL HistORY, supra note 1 , at 110.

${ }^{18}$ Id. at 93, 110, 131.

${ }^{19}$ Whittington, New Originalism, supra note 14, at 601; Delahunty \& Yoo, supra note 4.

${ }^{20}$ Whittington, New Originalism, supra note 14 at 603.

${ }^{21}$ Id. at 602; O'NEILl, CONSTITUTIONAL HISTORY, supra note 1, at 107.

${ }^{22}$ Whittington, New Originalism, supra note 14, at 601. 
Supreme Court. Academics like Paul Brest and Jefferson Powell raised import questions about the theory. How could a single intent be derived from the often-conflicting concerns of multiple authors? What is the proper level of abstraction at which that intention should be described? Should it matter that the founders themselves did not believe their intentions were binding? And why should the 'dead hand' of the past control modern American government? ${ }^{23}$ Changes on the Court produced further challenges. ${ }^{24}$ When Rehnquist, Scalia, and other originalists joined the Court, the theory needed to do more than critique a handful of Warren Court decisions. It had to justify the exercise of judicial review more broadly. $^{25}$ Intellectual developments shaped the response to these challenges. Most important was the growing interest in history, which was shared by leading non-originalist scholars like Akil Amar and Bruce Ackerman, ${ }^{26}$ and hermeneutic theory's concern with textual meaning. ${ }^{27}$

The result was 'New Originalism.' Unlike its predecessor, New Originalism offers a comprehensive theory of constitutional interpretation based on the original meaning of the constitution. ${ }^{28}$ It is not just a critique of the Warren Court, nor a mere effort to encourage judicial restraint. It is an attempt to identify the proper role of the judge in our constitutional democracy. ${ }^{29}$ As a result, its appeal has not been limited to conservatives. It has attracted scholars from a variety of political perspectives, including libertarians like Randy Barnett and progressives like Jack Balkin. ${ }^{30}$

This account of originalism's past was developed and deployed to clarify changes in the normative debates over the theory. But in doing so it has offered an explanation for originalism's development: why the theory emerged, why it changed form from old to new originalism, and why it has won ardent defenders. That explanation emphasizes the role of principled constitutional argument. Originalism, in this account, was produced by concerns with the legitimacy of the Warren Court's approach to

${ }^{23}$ Id. at $605-06$.

${ }^{24}$ See id. at 603-04.

${ }^{25}$ See id. at 604.

${ }^{26}$ Solum, Heller, supra note 14, at 932. See also, G. Edward White, The Arrival of History in Constitutional Law Scholarship, 88 VA. L. REV. 485 (2002) [hereinafter White, Arrival of History].

${ }^{27}$ Whittington, New Originalism, supra note 14, at 606.

${ }^{28}$ Solum, Heller, supra note 14, at 933.

${ }^{29}$ Whittington, New Originalism, supra note 14, at 608-09.

${ }^{30}$ See Lawrence B. Solum, Legal Theory Lexicon: Originalism, LEgAL THEORY BLOG (Nov. 16, 2014, 7:13 PM), http://lsolum.typepad.com/legaltheory/2014/11/legal-theorylexicon-originalism.html; Barnett, Nonoriginalists, supra note 4, at 611-12 [hereinafter Solum, Lexicon]. 
constitutional interpretation, shaped by the earnest efforts of academics to find a principled approach to constitutional interpretation, and attracted broad support because those academics shaped it into a plausible, practical, and principled theory of constitutional interpretation. ${ }^{31}$

\section{Originalism's Political Past}

This emphasis on principled argument as a way to explain originalism's emergence and development is not shared by a second set of scholars, who were attracted by different reasons to investigate a different aspect of originalism's past. Robert Post, Reva Siegel, Dawn Johnsen, Mary Ziegler, and others have investigated what they call 'originalism as political practice.' They have asked why interest groups chose to deploy originalist arguments, how originalism is related to the goals of the conservative movement, and what lessons originalism's success can teach progressives. ${ }^{32}$ They focused on actors outside the academy-primarily politicians and interest groups - and how those actors used the theory to advance their political interests. That focus made them quite skeptical that principled argument is responsible for the ways that originalism has changed over time. They concluded instead that originalism emerged to help conservative activists legitimate their political interests, changed as those interests changed, and has been so broadly adopted because it does that job well. ${ }^{33}$

Robert Post and Reva Siegel sparked this investigation. ${ }^{34}$ In a seminal article, they concluded that originalism was a more or less blatant effort 'to alter the Constitution so as to infuse it with conservative political principles.' ${ }^{35}$ Its success, they continued, 'does not reflect the analytic force

${ }^{31}$ Barnett, Nonoriginalists, supra note 4, at 617; see also McConnell, supra note 14; Randy E. Barnett, The Gravitational Force of Originalism, 82 FORDHAM L. REV. 411 (2013) [hereinafter Barnett, Gravitation]; Whittington, New Originalism, supra note 14.

${ }^{32}$ See, e.g., Ziegler, Originalism Talk, supra note 5; Johnsen, Lessons from the Right, supra note 5.

${ }^{33}$ Mary Ziegler, Grassroots Originalism: Judicial Activism Arguments, the Abortion Debate, and the Politics of Judicial Philosophy, 51 U. LOUISVILLE L. REV. 201 (2013) [hereinafter Ziegler, Grassroots]; Neil S. Siegel, Interring the Rhetoric of Judicial Activism, 59 DePAul L. REV. 555, 558-62 (2010); Jamal Greene, Selling Originalism, 97 GEO. L.J. 657, 696, 716 (2009) [hereinafter Greene, Selling] ("The success of originalism results not from its penetrable logic, but from its consistency with a political morality defended most ardently by originalism’s opponents.”) (noting originalism also is successful because it appears value-neutral); Stefanie A. Lindquist, Joseph L. Smith \& Frank B. Cross, The Rhetoric of Restraint and the Ideology of Activism, 24 CONST. COMMENT. 103, 104-06 (2007); Post \& Siegel, supra note 1, at 549.

${ }^{34}$ Post \& Siegel, supra note 1.

${ }^{35} \mathrm{Id}$. at 561 . 
of its jurisprudence, but instead depends upon its capacity to fuse aroused citizens, government officials, and judges into a dynamic and broad-based political movement. ${ }^{36}$

To support these claims, they showed the political uses of originalism. Ronald Reagan invoked it justify his appointments of Scalia, Rehnquist, and others judges, who he expected to advance a narrow, conservative, ideological agenda. Conservative outcomes, not neutral processes, were his goal. ${ }^{37}$ Conservative lawyers used originalism to legitimate litigation they hoped would advance conservative preferences, not neutral principles. ${ }^{38}$ Republican politicians used the theory to urge their supporters into action. ${ }^{39}$ On the bench, it served the same ends. Scalia's dissent in Lawrence $v$. Texas was exemplary of his efforts to mobilize conservative voters through his opinions. ${ }^{40}$ And Scalia, Thomas, and other originalist judges used the past to justify their conservative views when they could, then ignored it when they could not. ${ }^{41}$

Leading conservative intellectuals, interest groups, and politicians shaped originalism to fit their political preferences. Focus on the Family identified it with support for religious freedom and opposition to abortion, the right to homosexual sex, and obscenity. ${ }^{42}$ Socially conservative organizations like Liberty Counsel 'cashed out' terms like the 'respect for the Constitution' and for the 'rule of law' as fidelity to 'traditional values of religion, gender, and family. ${ }^{43}$ Even for academics, originalism was a political tool. Robert Bork, they argued, saw originalism as a call for the restoration of a particular set of morals and customs. ${ }^{44}$ Originalism, in this view, was not a result of a principled search for the Constitution's original meaning. It was simply a re-description of conservative political values.

The theory has not changed over time in response to principled argument; it arose to help conservatives criticize the liberal results of the Warren Court ${ }^{45}$ then changed along with conservative politics. ${ }^{46}$ When research suggested originalism would allow segregated schools in the District of Columbia, conservative advocates ignored it. '[T]hose who

\footnotetext{
${ }^{36}$ Id. at 549.

${ }^{37} \mathrm{Id}$. at 556 .

${ }^{38} \mathrm{Id}$. at 575.

${ }^{39} \mathrm{Id}$. at 565 .

${ }^{40} \mathrm{Id}$. at 567.

${ }^{41} \mathrm{Id}$. at 562, 565.

${ }^{42}$ Id. at 556 n.54.

${ }^{43} \mathrm{Id}$. at 573 .

${ }^{44} \mathrm{Id}$. at 560 n.74.

${ }^{45} \mathrm{Id}$. at 547.

${ }^{46}$ Id. at 558.
} 
guided the political practice of originalism had no intention of assaulting Bolling [v. Sharpe], much less Brown [v. Board of Education]. ${ }^{47}$ Originalists initially opposed the incorporation doctrine, but now agree the First Amendment applies to the states. ${ }^{48}$ Originalists once opposed elevated scrutiny for sex-based classifications. Now they support it. ${ }^{49}$ Those changes were not a result of disinterested research. They were efforts to align originalism with the latest developments in conservative politics. ${ }^{50}$

Research by other scholars into archival sources and interviews offers an opportunity to open dialogue between originalism's two histories, as I will discuss later, but it has also extended Siegel and Post's insights. Steve Teles, Mary Ziegler, and Jefferson Decker have confirmed that originalism's political value was well understood by conservative activists. ${ }^{51}$ Steve Teles's study of the Meese Justice Department showed that the Department turned to originalism in 1985 to justify legal policies that the Reagan Administration was already pursuing. ${ }^{52}$ In Reagan's first term, the Department sold those policies on a case by case basis, with unsatisfactory results. ${ }^{53}$ In the second term, the Department used originalism to legitimate those same policies to legal experts and the public. ${ }^{54}$ Meese's speechwriter recalled that the public discussions of originalism were a way to

....give a philosophical context for those policy disputes [including abortion and the Miranda v. Arizona decision], to elevate the conservative legal view, to 'these are not just the policies that support the business community, but these are political and legal issues that are rooted in something more transcendent than the disputes of the moment.'....The speeches, the rhetorical dimension of the department, were to give context for all those other, more mechanical activities,

${ }^{47} I d$.

${ }^{48}$ Id. at $559-60$.

${ }^{49}$ Id. at 559 .

${ }^{50} I d$.

51 See JefFerson Decker, The Other Rights Revolution: Conservative LAWYERS AND THE REMAKING OF AMERICAN GOVERNMENT (2016); Ziegler, Originalism Talk, supra note 5; Ziegler, Grassroots, supra note 33; Steven M. Teles, Transformative Bureaucracy: Reagan's Lawyers and the Dynamics of Political Investment, 23 STUD. AM. PoL. DeV. 61 (2009) [hereinafter Teles, Transformative Bureaucracy].

${ }^{52}$ Teles, Transformative Bureaucracy, supra note 51, at 76.

${ }^{53} \mathrm{Id}$. at 77 .

${ }^{54} \mathrm{Id}$. 
like filing suits and joining as amicus. ${ }^{55}$

Originalism was many things, but for the conservative officials who advanced it during Regan's presidency, it was a tool to legitimate conservative policies.

Likewise, the right to life movement saw originalism as a tool to help them curb abortions. ${ }^{56}$ Mary Ziegler studied the movement's decision to adopt originalism by supplementing public documents with internal memoranda of the Reagan Administration, the National Right to Life Committee, and other interest groups. ${ }^{57}$ Prior to the Bork nomination, the pro-life movement opposed originalism and used natural law and human rights theories to argue the $14^{\text {th }}$ Amendment created a constitutional right to life for the unborn. ${ }^{58}$ Their claims were inconsistent with the theory of originalism and its implications, which called for overruling of Roe v. Wade and the return of abortion rights questions to the political processes of the states. ${ }^{59}$ The movement did not even welcome originalism when Meese made it the official constitutional theory of the Reagan Administration. ${ }^{60}$

They changed their position only when they saw the political benefits of joining the originalist coalition. ${ }^{61}$ Their natural law and fundamental rights arguments failed to convince lower courts to recognize that the unborn had a legal right to life. ${ }^{62}$ The Supreme Court also seemed unwilling to change that basic assumption. ${ }^{63}$ Efforts to 'confirm' the $14^{\text {th }}$ Amendment provided a right to life with a constitutional amendment failed. ${ }^{64}$ And the movement saw that opposing originalism limited their influence over Reagan's judicial appointments. ${ }^{65}$ When the Bork nomination failed, these concerns led them to publicly embrace originalism. ${ }^{66}$ This was not a change of heart. Among themselves, they continued to agree that the fetus had a constitutional right to life supported

${ }^{55} I d$. (quoting Interview with McDowell, July 2007).

${ }^{56}$ Ziegler, Originalism Talk, supra note 32, at 920.

${ }^{57}$ Id. at $907-20$.

${ }^{58} \mathrm{Id}$. at $881-82$.

${ }^{59}$ Id. at 898, 919 ("[T] before Roe .... stood in tension with interpretive theories centered on the idea of original intent”).

${ }^{60}$ Id. at 882.

${ }^{61}$ Id. at $919-20$.

${ }^{62}$ Id. at $904-05$.

${ }^{63}$ Id. at 913 (citing City of Akron v. Akron Ctr. for Reprod. Servs., 462 U.S. 416

(1983), overruled by Planned Parenthood of Se. Pa. v. Casey, 505 U.S. 833 (1992)).

${ }^{64} \mathrm{Id}$. at 898-904.

${ }^{65} \mathrm{Id}$. at 919.

${ }^{66} I d$. 
by natural law readings of the 14 th Amendment. ${ }^{67}$ But publicly they deployed originalist arguments to criticize pro-choice Justices and to endorse pro-life, Republican appointees. Originalism was a tool to expand their influence over Republican judicial appointees, undermine Roe $v$. Wade, and decrease abortions. ${ }^{68}$

This view presents originalism as a post-hoc rationalization for conservative political goals. ${ }^{69}$ It gives conservatives grudging respect for making originalism into a powerful tool for legitimating their politics, but it is political motives that drive originalism's development. Principle does not play an important role, a stark contrast to the account offered by originalism's advocates.

\section{A Divided History of a Connected Subject}

The difficulty with these two literatures is not that they examine originalism in different contexts. The theory has played an important role in both academic debate and political life. Nor is it troublesome that they pursue different goals. It is entirely legitimate to look to originalism's past to learn how politics shaped the theory's uses and to discuss originalism's past to clarify ongoing normative debates. The problem is that the two literatures do not engage one another, which diminishes our understanding of the theory's development over time and its role in law and politics. There is a sharp division between the two historical accounts of originalism, but clear connections between the orginalism's academic and political life.

From the inception of modern originalism political actors have regularly responded to and used the products of academics. Raoul Berger's Government by Judiciary is considered by many the starting point for modern originalist theory, ${ }^{70}$ and its publication was immediately hailed by William F. Buckley in the pages of the National Review, the magazine many consider the starting point for the intellectual integration of the modern Republican Party. ${ }^{71}$ In 1987, the Department of Justice published a

${ }^{67}$ Id. at 921.

${ }^{68} \mathrm{Id}$.

${ }^{69}$ See Katharine T. Bartlett, Tradition as Past and Present in Substantive Due Process Analysis, 62 DukE L.J. 535, 548 (2012); Jamal Greene, Nathaniel Persily \& Stephen Ansolabehere, Profiling Originalism, 111 CoLUM. L. REV. 356 (2011); Johnsen, Lessons from the Right, supra note 5; Greene, Original Intent, supra note 13, at 1689; Post \& Siegel supra note 1 .

${ }^{70}$ O’Neill, Constitutional History, supra note 1; Greene, How Constitutional Theory Matters, supra note 10.

${ }^{71}$ Ken I. Kersch, Ecumenicalism Through Constitutionalism: The Discursive Development of Constitutional Conservatism in National Review, 1955-1980, 25 STUD. 
'Guide to Litigators in Constitutional Cases,' which ostensibly set out the approach government litigators should take to arguing constitutional cases. It made originalism as the official interpretive theory of the Reagan Justice Department and many of its claims were backed by citations to Robert Bork, Raoul Berger, and other early originalists. ${ }^{72}$ Similarly, The Constitution in the Year 2000, another publication of the DOJ's Office of Legal Policy, regularly cited the research of originalist academics to support the goals of the conservative leadership of the DOJ. ${ }^{73}$

Academic debate regularly responds to originalist argument by political actors. The Court, of course, continually sparks debate. Consider the attention District of Columbia v. Heller sparked in law reviews. ${ }^{74}$ But more traditional political actors shape legal debate as well. Attorney General Ed Meese, for example, secured originalism's place in academic debate when he announced the Reagan Administration's embrace of the theory. ${ }^{75}$ Critics of originalism responded to Meese's claims. ${ }^{76}$ Its academic

AM. Pol. DEV. 86 (2011) [hereinafter Kersch, Ecumenicalism]; William F. Buckley Jr., Berger's Big Book, NAT'L REV., Nov. 11, 1977, at 1320.

72 See OfFice of Legal Policy, U.S. DeP'T OF Justice, Guidelines ON CONSTITUTIONAL LiTIGATION 3 (1987) [hereinafter GUIDELINES ON CONSTITUTIONAL LITIGATION] (citing Robert Bork and urging government attorneys to advance arguments based on “original meaning”); GUIDELINES ON CONSTITUTIONAL LITIGATION, supra at 4 (citing RaOul Berger, Government by Judiciary: ThE Transformation of the FourteEnth AMENDMENT 5 (1977)); Dawn Johnsen, Windsor, Shelby County, and the Demise of Originalism: A Personal Account, 89 IND. L.J. 3, 16 (2014) [hereinafter Johnsen, Personal Account] (claiming that in these documents "the Reagan Administration relied heavily upon Judge Bork's writings”).

73 Office of Legal Policy, U.S. Dep't of Justice, Report to the AtTorney General, The CONSTITUTION IN THE YeAR 2000: ChOICES AHEAD IN CONSTITUTIONAL INTERPRETATION (1988) [hereinafter CONSTITUTION IN THE YEAR 2000]. This publication served as the model for THE CONSTITUTION IN 2020 (Jack M. Balkin \& Reva B Siegel eds., 2013).

74 See Jamal Greene, Heller High Water? The Future of Originalism, 3 HARV. L. \& POL’y REV. 325 (2009) [hereinafter Greene, Heller High Water]; Siegel, Dead or Alive, supra note 11; Saul Cornell, Originalism on Trial: The Use and Abuse of History in District of Columbia v. Heller, 69 OHIO ST. L.J. 625 (2008) [hereinafter Cornell, Originalism on Trial].

75 See Steven G. Calabresi, Originalism, A QuARter Century of Debate 4 (2007) [hereinafter CAlabresi, QuARTER CEnTURY]; Steven G. Calabresi, A Critical Introduction to the Originalism Debate, 31 HARV. J.L. \& PUB. POL’Y 875, 875 (2008) [hereinafter Calabresi, Critical Introduction] ("[The debate over originalism], which had been proceeding quietly in American law schools, burst into noisy and public view in July 1985 with a speech by then-Attorney General Edwin Meese III to the American Bar Association that called for a jurisprudence of original intention. Supreme Court Justice William J. Brennan, Jr., entered the fray that October with an address at Georgetown University, to which Meese responded the next month in a speech before the Federalist 
supporters stepped in to defend him. ${ }^{77}$

In addition, some of the same people have played an important role in originalism's political and academic life. Gary McDowell was a political scientist and an advisor to Attorney General Meese who argued for originalism in both positions. ${ }^{78}$ Stephen Calebresi worked closely with Meese when the Attorney General was promoting originalism most aggressively, then became one of originalism's most able defenders in academia. ${ }^{79}$ James McClellan spent much of his career as an academic political scientist, but also worked as Chief Counsel for the Subcommittee on Separation of Powers of the Senate Committee on the Judiciary when the GOP controlled the upper chamber. ${ }^{80}$ He later ran the Center for Judicial Studies, which advanced originalist arguments in public debate by publishing, among other things, Benchmarks, a law journal aimed at educating the public that regularly supported originalist arguments. ${ }^{81}$ Before entering academia, Mike Paulsen, Randy Beck, John McGinnis, Michael Rappaport, Doug Kmiec, and many others served in important roles in the Reagan and Bush Justice Departments, then became powerful advocates for

Society Lawyers Division. These speeches remain among the most enduring statements of the originalist creed and its critics.”) (footnotes and citations omitted).

${ }^{76}$ See Post \& Siegel, supra note 1; Paul Brest, Affirmative Action and the Constitution: Three Theories, 72 IOWA L. REV. 281, 281 (1987); H. Jefferson Powell, The Modern Misunderstanding of Original Intent, 54 U. CHI. L. REV. 1513 (1987); H. Jefferson Powell, Reaching the Limits of Constitutional Scholarship, 80 Nw. U. L. REV 1128 (1986) (reviewing LAURENCE H. TRIBE, CONSTITUTIONAL CHOICES (1985)); H. Jefferson Powell, Rules for Originalists, 73 VA. L. REV. 659 (1987).

${ }^{77}$ See generally, Daniel A. Farber, The Originalism Debate: A guide for the Perplexed 49 Оніо ST. L.J. 1085 (1989).

78 O’Neill, CONSTITUtional History, supra note 1 , at 137 . McDowell was the Associate Director of the Office of Public Affairs at the Justice Department. GARY L. McDowell, Curbing the Courts: The CONSTITUTION AND THE LiMITS OF JudiciAL POWER (1988); see also Teles, Transformative Bureaucracy, supra note 51, at 76.

${ }^{79}$ See, e.g., Steven G. Calabresi \& Andrea Matthews, Originalism and Loving v. Virginia, 2012 BYU L. REV. 1393 (2012); Steven G. Calabresi \& Julia T. Rickert, Originalism and Sex Discrimination, 90 TEX. L. REV. 1 (2011); Calabresi, Critical Introduction, supra note 75. Calabresi served as Special Assistant to Attorney General Meese from 1985-1987, when Meese was most active in promoting originalism. See Steven G. Calabresi Curriculum Vitae, NORTHWESTERN UNIVERSITY SCHOOL OF LAW http://www.law.northwestern.edu/faculty/assets/documents/cv-CalabresiStevenG_v201605-24;131601.pdf (last visited Jan. 15, 2017).

${ }^{80}$ Ralph Rossum, James McClellan, Benchmark, and an Informed Public, 54 MoD. AGE 7 (2012).

${ }^{81}$ Id.; MCDOWELL, supra note 78; James McClellan, The New Liberty of Contract Under the Thirteenth Amendment, Editor's Brief, BENCHMARK 3, November-December 1987, at 367; James McClellan, Review of the Reviews, BENCHMARK 2, May-August 1986 at $280-81$. 
originalist methods in the academy. ${ }^{82}$ Such interwoven relationships and repeated interactions strongly suggest that the enduring similarities between originalist argument in the academy and in politics did not occur by chance.

\section{Bridging the Divide: Investigating Political Influences on Principled Debate}

The durable similarities and repeated interactions between originalism's academic and political lives suggest that a dialogue between the theory's academic and political histories would be productive. The question is how to create that dialogue? One way is to follow the example of recent research on the conservative legal movement. Led by Steve Teles, scholars in a variety of disciplines have shown how conservative activists responded to the realization that electoral victories did not immediately transform public policy. ${ }^{83}$ Many policy arenas had been constitutionalized and when President Nixon's four Supreme Court appointees did not produce the counter-revolution conservatives hoped for, they looked for new strategies. ${ }^{84}$ Conservative interests like the Olin Foundation poured resources into organizations that could help produce legal change. ${ }^{85}$ They recruited lawyers of quality and distinction, found volunteers to fund

82 Faculty \& Staff: Mike Paulsen, University of ST. THOMAS SchOOL OF LAW, https://www.stthomas.edu/law/facultystaff/a-z-index/michael-paulsen.html (last visited Jan. 15, 2017); Randy Beck: Cirriculum Vita, UNIVERSITY OF GEORGIA SCHOOL OF LAW, http://www.law.uga.edu/sites/default/files/Curriculum\%20Vitae\%20-

\%20Short\%20Version\%202015.pdf (last visited Jan. 15, 2017); John Oldham McGinnis: Curriculm Vitae, NORTHWESTERN UNIVERSITY, PRITZKER SCHOOL OF LAW, http://www.law.northwestern.edu/faculty/assets/documents/cv-McGinnisJohnO_v2016-0318;084042.pdf (last visited Jan. 15, 2017); Faculty \& Research: Douglas W. Kmiec, J.D., PEPPERDINE SCHOOL OF LAW, http://law.pepperdine.edu/facultyresearch/faculty/?faculty=douglas_kmiec (last visited Jan 15, 2017). See, e.g., Randy Beck, The New Jurisprudence of the Necessary and Proper Clause, 2002 ILL. L. REV. 581 (2002); Michael Stokes Paulsen, Does the Constitution Prescribe Rules for its Own Interpretation? 103 Nw. U. L. REV. 857 (2009); John O. McGinnis and Michael B. Rappaport, Originalism AND THE GoOd CONSTITUTION (2013); Douglas W. Kmiec, Natural Law Originalism for the Twenty-First Century: A Principle of Judicial Restraint, not Invention, 40 SUFFOLK U. L. REV. 383 (2007). Other important scholars who served in the Reagan or Bush Justice Departments include Brad Clark, John Harrison, Gary Lawson, Nelson Lund, John Manning, and Michael McConnell.

83 Teles, Rise of the Conservative Legal Movement, supra note 7; HollisBruskey, supra note 7;

84 Teles, Rise of the Conservative LegAL Movement, supra note 7.

${ }^{85}$ Erin Cady, The John M. Olin Fellowships and the Advancement of Conservativism in Legal Academia, forthcoming, HARV. J. L. \& PUB. POL. (2016) (on file with author). 
lawsuits, developed intellectual resources, and then kept these assets connected and working together. ${ }^{86}$

The most successful of these organizations was The Federalist Society. Started with seed money from the Olin Foundation and the commitment of a group of law students, the Federalist Society has not only helped feed talented lawyers into the growing number of conservative public interest law firms, it has also helped credential a new set of judges and academics who have acted as intellectual entrepreneurs. It has been a remarkable success. ${ }^{87}$ Amanda Hollis-Bruskey has shown how closely connected the Federalist Society is with some of the most important conservative victories of the last two decades. Arguments were developed by Federalist Society academics, advanced by conservative public interest law firms staffed by Federalist Society lawyers, presented to law clerks who were members, and then embraced by Federalist Society judges, including Scalia, Alito, and Roberts. ${ }^{88}$

But the influence of this organizing on originalism is only beginning to be investigated. Teles has examined originalism's development in government, but how the purposeful creation of organizations to advance conservative goals has shaped the production of originalism has not been explored. ${ }^{89}$ Hollis-Bruskey's study of the Federalist Society recognizes that commitment to originalism is core commitment of its membership, but she focuses on the impact of the society, not how its commitments were developed. ${ }^{90}$ More research like Erin Cady's examination of the Olin Foundation could help reveal important connections. ${ }^{91}$

\section{Bridging the Divide: Investigating Principle's Influence on Political Debate}

A more serious challenge to generating dialogue between the academic and political histories of originalism is to show the way the principled debates of academics have shaped the political uses of the theory. Neither scholars concerned with originalism's political history nor those interested in its academic history have embraced the few claims that academic debates matter because conservative political actors share the

${ }^{86}$ TELES, Rise OF THE CONSERVATIVE LEGAL MOVEMENT, supra note 7.

${ }^{87}$ Id.

${ }^{88}$ Hollis-Bruskey, supra note 7.

89 Teles, Rise OF THE Conservative Legal Movement, supra note 7.

${ }^{90}$ Hollis-Bruskey, supra note 7.

91 See Cady, supra note 85 (tracing the support of the Olin Foundation for scholars who have supported originalism in academic debates). 
principled motives of scholars. Even scholars willing to consider whether principled argument has shaped the success of the conservative legal movement have focused on the impact those debates have had on the courts rather than on more traditional political actors.

Nevertheless, there is evidence that principle has shaped the way that conservative political actors have used originalism. What this section offers is an explanation for why that might be that does not depend on the dubious assumption that most, or even many, political actors are share academics' concern for legal and constitutional principle. Instead, this section assumes that political actors are motivated primarily - or perhaps even exclusively - by their political goals. It then explains why those political motivations might lead them to attend carefully to legal and constitutional principle. Finally, it argues that such a politically motivated concern with principle could lead conservative activists to shape their uses of originalism in ways that are attentive to academic debates.

\section{Principled Motives for Political Action}

The only express effort to write a unified history of originalism is Johnathan O'Neill's Originalism in American Law and Politics. ${ }^{92}$ His explanation for how the political and academic histories of originalism interact, however, has not been embraced by either of the two current histories of originalism. That may be in part because his narrative emphasizes the role principled motives played in shaping the political uses of originalism, a possibility both histories of originalism find dubious.

O'Neill's narrative indicates that the political and academic histories of originalism were connected because both were shaped by a similar concern with legal and constitutional principle. In the 1980s, he argued, there was a natural alignment between the majoritarian premises of both originalism and the conservative movement. Academics like Robert Bork and Raoul Berger were attracted to originalism because it advanced majoritarian democracy. This part of his narrative has been adopted by originalism's academic history. ${ }^{93}$ But he also argues that Originalism attracted political actors like Edwin Meese and others for similar reasons. It was originalism's majoritarian thrust, O'Neill wrote, that attracted the support of the Reagan administration and its supporters who 'regarded several Supreme Court decisions as politically distasteful, constitutionally mistaken affronts to limited, representative government. ${ }^{94}$ Originalism, he

\footnotetext{
92 O’NEILL, CONSTITUTIONAL HISTORY, supra note 1.

93 O’Neill, Bickel and Bork, supra note 11; O’Neill, Raoul Berger, supra, note 11.

94 O’NeILL, CONSTITUTIONAL HistORY, supra note 1, at 133-34, 146.
} 
wrote, was sometimes dismissed as a ploy to advance conservative policy goals. But, it was not merely a call for conservative results in constitutional adjudication. The reason for originalism's success in the 1980s was the theory's appeal 'to the principle and rhetoric of limited government[,] consent-based politics, .. . [and] its traditional understanding of the nature of constitutional interpretation. 95

Those suggestions have not been embraced. Siegel and Post's article was published a year after O'Neill's book and soundly rejected the claim that principle has played an important role in originalism's emergence and development in the political arena. ${ }^{96}$ For them and those that followed them, the conservative movement's use of originalism was merely camouflage for the politics that were really driving the theory's development. $^{97}$ Those interested in Originalism's academic history have been equally dubious that principle has played in important role in originalism outside the academy. Keith Whittington explicitly dismissed the influence of principle outside the academy when he described the emergence of the New Originalism. 'I have no particular illusions,' he wrote, 'about the consistency or sophistication of constitutional theorizing on the bench.' 98

Other scholars, including most prominently Jamal Greene, have suggested that principle may have shaped originalism's development outside academia, but they have not considered whether principle influenced traditional political actors. Greene argues that originalism succeeded not just because it advanced conservative policies but also because it had particular characteristics that made it an especially useful tool for that purpose. ${ }^{99}$ And, at moments, he suggests one of those characteristics was consistency with principle. ${ }^{100}$ A successful constitutional theory, he writes, 'requires both consistency with a dominant political agenda and an accompanying narrative that promises consistency with prevailing legal norms.' ${ }^{, 01}$ He further suggests that judges might be particularly concerned with a constitutional theory's consistency with legal principle because they could lose prestige and influence by advancing

\footnotetext{
${ }^{95} \mathrm{Id}$. at 134. Meese, he wrote, began his political campaign for originalism because of "a conviction among conservative activists that the intellectual structure of modern constitutional jurisprudence had to be confronted in a more direct and public manner.” Id. at 154.

${ }^{96}$ See supra notes 32-6950 and accompanying text.

${ }^{97}$ Greene, Selling, supra note 33, at 689.

${ }^{98}$ Whittington, New Originalism, supra note 14, at 599.

${ }^{99}$ Greene, Selling, supra note 33, at 657.

${ }^{100}$ Id. at 715.

${ }^{101} \mathrm{Id}$. at $714-15$.
} 
unprincipled theories. ${ }^{102}$ But ultimately he does not extend that argument to include traditional political actors, or explore how a concern with principle might have shaped originalism's development. ${ }^{103}$

There are good reasons for these doubts. At first glance it is unclear why hard-boiled political activists should care about the views of ivory tower academics. That is particularly true when those activists can develop arguments on their own, as the Meese Justice Department did. Under Meese's leadership, the Department dedicated tremendous energy to developing originalist ideas. It invited speakers, hosted discussions, and created opportunities for its lawyers to not just learn about originalism, but take part in shaping it. ${ }^{104}$ Justice Scalia, Judge Bork, and other luminaries of the conservative legal movement took part in these discussions. ${ }^{105}$ And the results poured out of the Department's Office of Legal Policy in a series of reports, source books, and directives, all of which helped define originalism. $^{106}$ If activists could develop originalist arguments that legitimated their political goals without the help of ivory tower academics, why listen to them?

\section{Political Motives for Principled Action}

Perhaps, however, those hard-boiled political activists cared about the limits of principled argument - and thus the debates of academics - not in spite of, but because of their political motivation. Perhaps principle might shape an actor's behavior even if it is not a motive for action. ${ }^{107}$ If so, conservative activists may well have seen constitutional principles as posthoc rationalizations for their political goals, but nevertheless felt constrained to shape their behavior to be consistent with those principles. And that concern with principle may have led them to attend to the state of academic debate, which helps determine the limits of principled argument.

The possibility of a politically motivated concern with principle can be developed from insights that reoriented intellectual history in the 1960s. ${ }^{108}$ Those insights emerged from work by University of Cambridge

${ }^{102}$ Id. at 703 (referring to principle as "consistency with the conventional forms of constitutional argument”).

${ }^{103}$ Id. at 708 .

${ }^{104}$ See Teles, Transformative Bureaucracy, supra note 51, at 79.

${ }^{105} \mathrm{Id}$.

${ }^{106} \mathrm{Id}$.

${ }^{107}$ Quentin Skinner, Some Problems in the Analysis of Political Thought and Action, 2 POL. THEORY 277, 292 (1974) (hereinafter Skinner, Some Problems].

${ }^{108}$ Kloppenberg, Thinking Historically, supra note 8; J. G. A. РососK, POLITICS, LANGUAGE, AND TIME: EsSAYS ON POLITICAL THOUght AND HiSTORY vii-ix (1971). 
colleagues J. G. A. Pocock, Peter Laslett, Quentin Skinner, and others who revolutionized the history of political thought by drawing on insights about the character of language that can be traced from J.L. Austin and other midtwentieth century philosophers of language, to Ludwig Wittgenstein and beyond. ${ }^{109}$ Those insights led the 'Cambridge School' to abandon the view that language was a relatively transparent medium for the representation of ideas. $^{110}$ Instead, they saw language as a historically situated social convention; both the meaning of individual words and the structures within which those words drew their meaning changed over time. ${ }^{111}$ As a result, they abandoned the effort to use intellectual history to answer perennial philosophical questions by finding in great texts a set of static fundamental concepts. ${ }^{112}$ Instead, the task they set themselves was to explain how and why particular changes in language occurred. ${ }^{113}$

This new focus produced at least two insights with important implications for today's history of originalism. One is that language, and the principles it describes, change as a result of politically motivated manipulations. '[P]olitical words,' wrote Daniel Rogers, 'take their meaning from the tasks to which their users bend them. They are instruments, rallying cries, tools of persuasion.' Or, as James Tully wrote, 'the pen is a mighty sword.' 114 This insight has been embraced by political history of originalism, which describes how conservatives have manipulated originalist arguments to advance their goals. ${ }^{115}$

But the view of language as a social convention has other implications, too. It also means there are limits to the ways political actors can manipulate language. ${ }^{116}$ If language is a social construct, the meaning it creates is not objective, but it is 'intersubjective,' that is: the criteria that

${ }^{109}$ Kloppenberg, Thinking Historically, supra note 8. A similar "linguistic turn” transformed other human sciences, as well. THE LINGUISTIC TURN: RECENT ESSAYS IN PHILOSOPHICAL METHOD, (Richard Rorty ed., 1967).

${ }^{110}$ John E. Toews, Intellectual History After the Linguistic Turn: The Autonomy of Meaning and the Irreducibility of Experience, 92 AM. HIST. REV. 879, 881-82 (1987).

${ }^{111}$ Gienapp, supra note 6; Cornell, Intellectual History, supra note 6; J. G. A. Pocock, supra note 108.

${ }^{112}$ Quentin Skinner, Meaning and Understanding in the History of Ideas, in MEANING \& CONTEXT: QUENTIN SKINNER AND HIS CRITICS, supra note 8 [hereinafter Skinner, Meaning and Understanding]; Kloppenberg, Thinking Historically, supra note 8; William J. Bouwsma, From History of Ideas to History of Meaning, 12 J. INTERDISC. HIST. 279 (1981).

${ }^{113}$ Pocock, supra note 10808; James Tully, Introduction to MEANING AND CONTEXT: QUENTIN SKINNER AND HIS CRITICS, supra note 8, at 7 [hereinafter Tully, Introduction].

${ }^{114}$ Tully, Introduction, supra note 113.

${ }^{115}$ Post \& Siegel, supra note 1.

${ }^{116}$ Toews, supra note 110. 
determine whether a term applies to a particular act are set by the term's common use, not by the assertions of the actor who is trying to manipulate it. ${ }^{117}$ As a result, when an actor tries to manipulate language to legitimate his behavior or political goals, he does not get to determine himself whether or not he has succeeded. ${ }^{118}$ The success of his attempted manipulation will be determined by the larger community of language users. That means an actor might to go too far in his attempts to, for example, manipulate an existing commendatory term so that could apply to his dubious actions. By 'going too far' he could make clear to observers that he had changed the term's meaning. He would thereby undermine his claim that his action was legitimate because it could be fairly described by the commendatory term. ${ }^{119}$ Alternatively, the actor could undermine his efforts to legitimate his behavior by acting in ways that made clear he was not motivated by the principles he espoused. ${ }^{120}$

The intersubjectivity of language might also limit the ability of actors to manipulate legal and constitutional principle. Legal principle might shape the behavior of hard-boiled political operatives using it only as a post-hoc rationalization because allowing it to shape their behavior would be the only way it could be an effective rationalization. When political actors use legal and constitutional principles to rationalize their behavior, they are doing it for a purpose. They are seeking to legitimate actions or policies they worry might otherwise be considered inappropriate or illegitimate. Under such circumstances, the actor would need to claim that his behavior was in fact motivated by some approved set of principles, and once he had done so, would then need to act in ways that make his claim seem plausible. Otherwise, those principles would fail to legitimate his actions. If he failed to act in accordance with his professed principles, those principles would not be effective tools for legitimation. ${ }^{121}$ One implication of this insight is that the courses of actions the actor could take would be limited by the range of principles that he could plausibly claim motivated his action. ${ }^{122}$ As a result, the problem facing an actor seeking to pursue a debatable course is not just how to shape existing principles to fit his goals,

\footnotetext{
${ }^{117}$ Tully, Introduction, supra note 113, at 13; Keith Michael Baker, On the Problem of the Ideological Origins of the French Revolution, in MODERN EUROPEAN INTELLECTUAL History: Reappraisals and New Perspectives, (Dominick La Capra \& Steven L. Kaplan eds., 1982); Cornell, Intellectual History, supra note 6.

${ }^{118}$ Tully, Introduction, supra note 113 , at 13.

${ }^{119}$ Skinner, Meaning and Understanding, supra note 112.

${ }^{120} \mathrm{Id}$.

${ }^{121}$ Quentin Skinner, 1 Visions of Politics: Regarding Method 134 (2002) [hereinafter SKINNER, REGARDING METHOD].

${ }^{122}$ Skinner, Some Problems, supra note 107107, at 299.
} 
but also how to shape his goals to fit the principles that might plausibly legitimate them. ${ }^{123}$ Principle, in other words, could shape a political actor's actions even if he saw them only as tools to advance his interests.

Leading contemporary historians of political thought have applied similar insights to great effect. ${ }^{124}$ And the claim that the limits of principled legal reasoning shaped political action is a core finding of some of the best recent legal history, a field where ideas and power collide 'head on.,125 Charles W. McCurdy, for example, showed how a popular property reform movement in the 19th century was shaped by the 'distinctive logics' of both party politics and law. ${ }^{126}$ Cynthia Nicoletti has applied a similar insight to ways that arguments about secession both shaped and was shaped by the Civil War and reconstruction. ${ }^{127}$ Other examples include recent studies of how legal ideas both shaped and were shaped by the fight for civil rights, ${ }^{128}$ welfare rights, ${ }^{129}$ workers' rights, ${ }^{130}$ the realignment of political parties, ${ }^{131}$ and the construction of the administrative state. ${ }^{132}$ Ken Kersch has described how constitutional discourse in politics helps build, undermine, and rebuild party and political regimes in a manner consistent with this insight. $^{133}$

${ }^{123}$ Skinner, Meaning and Understanding, supra note 112.

${ }^{124}$ DANiel T. Rodgers, Contested Truths: Keywords in American Politics SinCE INDEPENDENCE (1987); JAMES T. KLOPPENBERG, UNCERTAIN ViCTORY: SOCIAL DEMOCRACY AND PROgResSivism IN EUROPEAN AND AMERICAN THOUght, 1870-1920 (1986) [hereinafter KLOPPENBERG, UNCERTAIN VICTORY].

${ }^{125}$ Kloppenberg, Thinking Historically, supra note 8 at 207. See also G. Edward White, Transforming History in the Postmodern Era, 91 MiCH. L. REV. 1315 (1993) (reviewing MORTON J. HORWITZ, THE TRANSFORMATION OF AMERICAN LAW, 1870-1960: THE CRISIS OF LEGAL Orthodoxy (1992)) [hereinafter White, Transforming History].

${ }^{126}$ Charles W. MCCurdy, The ANTI-RENT ERA IN NEW YorK LAW AND Politics, 1839-1865 (2001).

${ }^{127}$ Cynthia Nicoletti, The Treason Trial of JefFerson Davis: SECESSion IN THE AFTERMATH OF THE CIVIL WAR (2017)

${ }^{128}$ Risa L. Goluboff, THe LOST Promise OF Civil RightS (2007).

${ }^{129}$ Karen M. TANi, States of Dependency: Welfare, Rights, and AMERican GOVERNANCE, 1935-1972 (2016).

${ }^{130}$ Sophia Z. LeE, The WorkPlace Constitution from the NeW DeAl to the NEW RIGHT (2014).

${ }^{131}$ Reuel Schiller, Forging Rivals: Race, Class, LaW, and the Collapse of POSTWAR LIBERALISM (2015).

${ }^{132}$ Daniel R. ERnSt, Tocqueville's Nightmare: The Administrative State EMERGES IN AMERICA, 1900-1940 (2014).

133 Ken I. Kersch, The Talking Cure: How Constitutional Argument Drives Constitutional Development, 94 B.U. L. REV. 1083 (2014) [hereinafter Kersch, The Talking Cure]. 
The same approach might also help explain how principled debates over originalism could shape the way conservative activists used the theory, even if they were using it as a rationalization. Certainly conservative activists like Meese and the pro-life movement saw originalism as device to legitimate their political preferences. ${ }^{134}$ And it is at least plausible that legal and constitutional principles legitimate action and have shared meanings that could limit the behavior of those trying to use them as tools.

Thus, legal principle could have shaped the development of originalism even if we accept that originalism is merely a rationalization for conservatism. An advocate of originalism motivated entirely by her political goals would see originalism as a tool to legitimate those goals to judges, politicians, the public, or, ideally, all three. Further, she would recognize that for originalism to be an effective tool for legitimating her goals, it would have to appear to be more than a mere rationalization for her conservative political preferences. To succeed in legitimating her political preferences, it must appear to be principled. As a result, she would try to ensure that her claims about originalism as a theory were consistent with relevant legal materials and our constitutional traditions. She would also make sure that her claims about originalism's implications were plausible interpretations of the existing historical evidence, relevant legal materials, and the theory itself. If those materials could plausibly justify only a limited range of arguments and actions, then this advocate would not simply alter originalism correspond to her goals political. She would work to ensure that her alterations of the theory were plausibly consistent with those principles, she would shape her claims about the theory's implications to ensure they too were plausible, and she may even choose to pursue a political strategy that was plausibly consistent with originalism rather than another that was not. What is more, such a politically motivated advocate would have good reason to attend to the debates of academics: those debates play an important role in determining what counts as principled debate, and what counts as off-the-wall raving. ${ }^{135}$ It is, for example, more difficult to dismiss an argument as frivolous when it has the support of the Charles Warren Senior Fellow in Legal History at Harvard Law School. ${ }^{136}$

${ }^{134}$ See supra notes 52-68 and accompanying text.

${ }^{135}$ See Jack M. Balkin, "Wrong the Day it was Decided": Lochner and Constitutional Historicism, 85 B.U. L. REV. 677, 679 (2005) (asserting that "the conventions determining what is a good or bad legal argument about the Constitution, what is a plausible legal claim, and what is 'off-the-wall' change over time in response to changing social, political, and historical conditions.... The internal norms of good constitutional legal argument are always changing, and they are changed by political, social, and historical forces”); Greene, How Constitutional Theory Matters, supra, note 10.

${ }^{136}$ See, O’Neill, Raoul Berger, supra note 11. 
This approach to the relationship of constitutional principle recognizes that principled debate might affect politics, but it does not simply reduce principle to politics, or ignore the complexities of academic life that make it more than politics by other means. It thus offers a way to bring the academic and political history of originalism into dialogue without reducing one to the other. It does not, of course, prove that legal principle had an important effect on the political uses of originalism. Nor does it prove that politics, rather than principle, motivated originalism's advocates. Those are empirical question. And one can fairly question whether this argument is based on a simplistic and inaccurate view of the relationship between interests and ideas, politics and principle, and political, social, and intellectual history. One may see interests shaping ideas just as those ideas help actors to determine their interests. Ideas and action may be opposite sides of the same coin. Efforts to pry them apart may be doomed to failure, as might efforts to separate social, intellectual, and political history. 'All social activity,' Keith Michael Baker has reminded us, 'has an intellectual dimension that gives it meaning, just as all intellectual activity has a social dimension that gives it its point. ${ }^{137}$ This essay, however, does not try to resolve those devilishly difficult issues because doing so is not necessary to create a productive dialogue between originalism's political and academic histories.

What this essay does claim is that there are good reasons to investigate how the principled debates of academics have shaped the political uses of originalism. That effect might occur because politically motivated conservative activists believe at least some respect for principle is necessary to make originalism an effective tool. It might occur because those conservative activists have mixed motives. It might occur because it is impossible to differentiate principle and politics, ideas and action. It might occur because of a combination of those reasons, or for some other reason. This essay has assumed a straightforward division between ideas and action and emphasized the political motives of conservative activists to show that principled debates might have shaped originalism's political uses even if we make the most cynical assumptions about the motivations of conservative activists and the role of ideas in politics. By doing so it hopes to show that questions about the relationship between principle and politics in originalism's past cannot be simply assumed away.

\section{Emerging from the Archives, a New History of Originalism}

\footnotetext{
${ }^{137}$ Baker, supra note 117.
} 
The potential of this approach is implicit in a handful of works that offer a glimpse of a what a new history of originalism could be. That scholarship is not part of a self-conscious discussion, but its paucity does not undermine its potential. Even if its authors did not fully recognize it, their work brings to the study of originalism a new approach that might transform the field. Their work differs methodologically from other examinations of originalism's past because it looks past traditional legal materials like judicial opinions and law review articles to archival and other sources. It then uses the results of that difficult historical spadework to illuminate with more precision the reasons political activists turned towards originalism and how that choice affected their behavior. It thus provides the insights necessary to reconsider the interaction of academic debate and political action in originalism's past.

One example of this new approach is Mary Ziegler's examination of the pro-life movement and its decision to embrace originalism, discussed above. ${ }^{138}$ She shows that the leadership of the pro-life movement embraced originalism not because of principle but because of politics. They publicly abandoned their natural law constitutionalism only after it failed in court and in Congress, and only after they realized supporting originalism would help them advance their goals in the Reagan administration. ${ }^{139}$ But this strategy had costs. ${ }^{140}$ When they adopted originalism they abandoned their fight to establish that a fetus had not just a moral, but a constitutional right to life grounded in the 14th Amendment. ${ }^{141}$ Instead, they, like other originalists, argued abortion should be regulated by the political process of the states, not the judiciary. ${ }^{142}$ Energy they had poured into changing public attitudes with constitutional and moral arguments was re-directed towards a debate over constitutional interpretation. ${ }^{143}$ When they became originalists, Ziegler wrote, 'abortion opponents had to down-play their most deeply held constitutional commitments. Instead of building support for their fundamental beliefs, abortion opponents turned to [originalist] rhetoric that promised an immediate political payoff. ${ }^{, 144}$

But why did the pro-life movement's leadership have to publicly abandon those cherished principles? Why could they not keep their originalist cake of immediate political gain and enjoy their deeply held

\footnotetext{
${ }^{138}$ Ziegler, Grassroots, supra note 33.

${ }^{139}$ Id. at 15, 25, 28.

${ }^{140} I d$. at 28; See Ziegler, Originalism Talk, supra note 5, at 872.

${ }^{141}$ Ziegler, Grassroots, supra note 33, at 28.

${ }^{142}$ Id. at 29.

${ }^{143}$ Id at 30.

${ }^{144}$ Id. at 8 .
} 
commitments, too? The evidence indicates the pro-life movement made that choice out of respect for legal principle, which they respected not in spite of, but because of, their political motivations. The movement did not abandon those commitments because of politics alone. Certainly they did not change their views on the right to life. ${ }^{145}$ Nor does it seem they were motivated by constitutional principle. When they embraced originalism, most members of the movement were not convinced originalism was the best way to interpret the constitution. ${ }^{146}$

Instead, it was their political motives that led them to respect the principled implications of originalist argument and, in turn, accept those painful trade-offs. They adopted originalism to legitimate their opposition to abortion rights: to undermine Roe v. Wade, to generate support for prolife politicians, and to gain influence with the Reagan administration. ${ }^{147}$ To succeed in that project, they needed to act and argue as though they were motivated by originalism's principles. Otherwise, originalism would fail to legitimate their claims. As a result, they supported only those claims that were plausibly consistent with originalism as it was understood. Because they could not plausibly claim that originalism established that a fetus had a right to life anchored in the Fourteenth Amendment, they had to abandon that claim and its potential benefits. They respected the limits of originalist argument, not in spite of, but because of their political motives.

Another example is Jefferson Decker's analysis of how conservative lawyers inside the Reagan Administration used originalism when arguing amongst themselves over Fifth Amendment takings jurisprudence. The issues arose when First English Lutheran Church of Glendale v. County of Los Angles was appealed to the Supreme Court. ${ }^{148}$ In First English, a fire and flood had destroyed a camp and retreat owned by the First English Lutheran Church. The church wanted to rebuild, but had to wait twenty-two months because City of Los Angles refused to provide the necessary permits. ${ }^{149}$ The church argued that delay was improper and that it was thus due compensation for this temporary and improper limit on the use of its land.

The appeal presented an exciting opportunity to Roger Marzulla and Thomas Hookano, two economic conservatives in the Environment and Natural Resources Division of the Department of Justice. Prior to

${ }^{145} I d$ at 29.

${ }^{146} I d$. at 25.

${ }^{147} I d$. at 31 . (1987)

${ }^{148}$ First English Lutheran Church of Glendale v. Cty. of Los Angles, 482 U.S. 304

${ }^{149} I d$. 
government service they had worked at leading conservative public interest law firms to expand the protections the Fifth Amendment's takings clause provided landowners. ${ }^{150}$ First English offered a way to continue that work by throwing the weight of the administration behind the claim that the Fifth Amendment protected landowners from 'temporary regulatory takings.' The Fifth Amendment had always required the government to compensate landowners when the government took ownership of their land for public purposes. But Marzulla and Hookano believed that landowners should be compensated when government regulations improperly limited the use of their land, even when the limit was only temporary. ${ }^{151}$

Marzulla and Hookano, however, had a problem because Charles Fried disagreed with them, and he was Solicitor General. ${ }^{152}$ Among other things, Fried feared such a doctrine would make it too easy for landowners to raid the treasury. ${ }^{153} \mathrm{~A}$ better way to for the courts to police illegitimate government regulation, he believed, was the more lenient doctrine that had developed as part of the Court's 14th Amendment's due process jurisprudence. ${ }^{154}$ Marzulla and Hookano tried to go over Fried's head. They reached out directly to Attorney General Meese to argue their brief, rather than Fried's, should be sent to the Court. ${ }^{155}$ Isolated and opposed to powerful interests inside the administration, Fried needed support. ${ }^{156} \mathrm{He}$ found it in originalism.

Fried does not seem to have turned to originalism because of his dedication to the theory as a matter of principle. His later rejection of originalism suggests he was a lukewarm originalist, at best. ${ }^{157}$ But First English occurred in the shadow of the public debate over originalism. Months earlier the administration had made originalism its official interpretive method, and in that Fried saw an opportunity. The founders, he wrote the Attorney General, would have easily distinguished an onerous regulation from a taking and thus would have denied 'temporary regulatory takings' existed. 'Our respect for original intent makes us hostage to Clio,' he wrote Meese, 'and we must accept the consequences.' 158

Fried's invocation of originalism may not have been driven purely

${ }^{150}$ DECKER, supra note 51 , at $1-2$.

${ }^{151} \mathrm{Id}$.

${ }^{152}$ Id. at $4-7$.

${ }^{153} \mathrm{Id}$. at 5 .

${ }^{154}$ Id. at 6 .

${ }^{155}$ Id. at 5 .

${ }^{156} I d$. at 9 .

${ }^{157}$ Charles Fried, Order and Law: Arguing the Reagan Revolution: A FIRSTHAND ACCOUNT 62-68 (1992).

${ }^{158}$ Id. at 5-6. 
by principle, but the theory was also not just politics. Fried invoked originalism to legitimate his position. He expected it to work because he expected Meese and other conservatives inside the administration to respect the principles they had been vigorously advocating in public. And it seems he was right. Invoking originalism helped him fight to a draw against a politically powerful group within the administration. ${ }^{159}$ The economic conservatives ultimately won the war. The Court in First English endorsed the idea of temporary regulatory takings. But originalism helped Fried stop the administration from calling on the Court to do so. The government's brief in the case adopted a compromise position, which fully satisfied neither Fried nor his inter-administration opponents. ${ }^{160}$

This event, Decker argued, suggests there was a real

....commitment to (some sort of) originalism by (some) key
people within the Reagan administration. And it
demonstrates that this commitment could have real
consequences. Originalism offered Charles Fried a way to
push back against a line of advocacy that he considered to
be radical and dangerous-and of defending that push-back
to his attorney general. For that reason, the Reagan
administration's public commitment to a certain way of
reading the Constitution served as a genuine constraint on
the policy outcome that many in his administration would
have preferred.

Decker, like Ziegler, did not explicitly consider whether the constraints he identified were the result of political motivations. But his research, like hers, went beyond law reviews, judicial opinions, and published sources to recapture examples of principle shaping the behavior of the Meese Justice Department and the pro-life movement. And like Ziegler, he did so without denying the clear importance of political motives. Together, their work offers a glimpse of what a new history of originalism might look like if we recognize that it is not necessary to make heroic assumptions about the motivation of political activists in order to consider whether principle might shape their behavior.

The next step towards bringing originalism's academic and political histories into dialogue is to consider how academic debate shaped what

\footnotetext{
${ }^{159}$ DECKER, supra note 51.

${ }^{160} \mathrm{Id}$.

${ }^{161}$ See Jefferson Decker, Originalism, Legal Policy, and the Reagan Administration, Conference Paper at the Policy History Conference (June 4-7, 2014) (on file with author).
} 
counted as a principled use of originalism. This is something neither Decker nor Ziegler explicitly considered, but there is suggestive evidence elsewhere. As discussed above, there has been significant overlap in both the topics that have interested originalism's academic and political proponents, and sometimes those proponents have been the very same people. $^{162}$ In addition, Ken Kersch has made clear at least one example of an academic shaping the political debate over originalism. Before Raoul Berger, originalist argument was a minor theme among the conservative activists clustered around the National Review, and sometimes it was explicitly rejected. But that changed after Raoul Berger added his respected academic voice to earlier calls for originalism by Robert Bork and then Justice Rehnquist. 'With the publication of Harvard Law Professor Raoul Berger's manifesto Government by Judiciary in 1977,' Kersch wrote, 'the center of gravity of conservative constitutional thought moved decidedly [and] rooted itself in a commitment to the interpretive theory of "originalism.", 163 Even if those activists saw Berger's academic prestige as nothing more than a tool to legitimate their preferences, Kersch still makes his influence clear. That, in turn, suggests that academics may have helped set the limits of principled debate which even the most cynical, hard-boiled, political motivated activists felt would be wise to respect. ${ }^{164}$

\section{Conclusion}

One of the byproducts of the emergence of New Originalism is a welcome interest in originalism's past. It has led originalism's proponents to look to the theory's past to differentiate their arguments from the Old Originalism of the 1980s. ${ }^{165}$ New Originalism's rise has also confirmed that originalism more broadly has survived decades of pounding from its critics. It may even be thriving. ${ }^{166}$ That success has led other scholars to ask how

\footnotetext{
${ }^{162}$ See, supra notes 783-91 and accompanying text.

${ }^{163}$ Kersch, Ecumenicalism, supra note 71, at 113; see also O’NEILL, CONSTITUTIONAL HistoRY, supra note 1, at 129-32; Greene, Original Intent, supra note 13, at 1684.

${ }^{164}$ O’Neill, Raoul Berger, supra note 11; William H. Rehnquist, Comment, The Notion of a Living Constitution, 54 TEX. L. REV. 693 (1976); Robert H. Bork, Neutral Principles and Some First Amendment Problems, 47 InD. L.J. 1 (1971). O’NeILL, ConstiTuTiONAL History, supra note 1 at 129-32.

${ }^{165}$ See Cornell, Intellectual History, supra note 6; James E. Ryan, Laying Claim to the Constitution: The Promise of New Textualism, 97 VA. L. REV. 1523 (2011).

${ }^{166}$ Balkin, New Originalism, supra note 14; Solum, Lexicon, supra note 30; Barnett, Nonoriginalists, supra note 4.
} 
that feat was accomplished and what we can learn from it. ${ }^{167}$

Unfortunately, the accounts of originalism's past have largely developed independent of one another. Each has its own explanation for originalism's emergence and development over time. One emphasizes the role of political interest. ${ }^{168}$ The other emphasizes the influence of principled argument. ${ }^{169}$ This division is unproductive and unnecessary. We might find a way to create a productive dialogue between these histories. We might do so, first, by attending to the ways that conservative political interests have affected academic debates by shaping the institutions that produce those debates. And, second, we might recognize that even an advocate of originalism motivated purely by politics might pay careful attention to academic debates to ensure his arguments about the theory were plausible, and then conform his behavior to match those arguments.

Opening a path to a new history of originalism offers new opportunities to learn from originalism's past. If we want to understand how constitutional theory has influenced politics, ${ }^{170}$ it is not enough to ask whether Charles Fried's arguments in the First English litigation were motivated by a principled commitment to originalism's truth or by his policy differences with economic conservatives in the Reagan administration. ${ }^{171}$ We also need to ask how and to what extent originalism helped him change the Department's policy. ${ }^{172}$ If we want to know what lessons originalism offers to the left, ${ }^{173}$ it is not enough to know if the leadership of the pro-life movement saw originalism as the most principled method of constitutional interpretation or as useful camouflage for its political agenda. We also need to ask what originalism offered them and how embracing it shaped their behavior. ${ }^{174}$

In this new history of originalism we can also begin to see something else: an underappreciated role that academic debate plays in the process of political change. Scholars have noted that academic debates can

${ }^{167}$ Greene, Original Intent, supra note 13; Greene, Persily \& Ansolabehere, supra note 69; Post \& Siegel, supra note 1.

${ }^{168}$ Greene, Persily \& Ansolabehere, supra note 6969; Post \& Siegel, supra note 1.

${ }^{169}$ Solum, Unwritten, supra note 4; WHITTINGTON, CONSTITUTIONAL INTERPRETATION, supra note 4.

${ }^{170}$ See Ziegler, Grassroots, supra, note 33; Greene, How Constitutional Theory Matters, supra note 10.

${ }^{171}$ First English Lutheran Church of Glendale v. Cty. of Los Angles, 482 U.S. 304 (1987).

${ }^{172}$ See DECKER, supra note 51.

${ }^{173}$ See Johnsen, Lessons from the Right, supra note 5; Post \& Siegel, supra note 1.

${ }^{174}$ See Ziegler, Grassroots, supra note 33. 
influence legal actors by legitimating particular arguments. ${ }^{175}$ But a new history of originalism might show those debates also shaped the behavior of political actors, too. Surely, academic debates are not the only influence on the political uses of originalism. Political interest must play a central role. But perhaps the relationship between ideas, interests, and institutions, between academics and politicians, is both more subtle and more important than it currently appears.

This dialogue is not all that is necessary to build the more accurate and complete history of originalism that we need to help manage the theory's uncertain future. Such a history also needs to embed the interaction of legal principle and political interest in a broader context. To understand the theory's interaction with politics, we need to look beyond originalism's ability to advance particular policies. Exemplary is Ken Kersch's examination of the role the theory played in helping to create modern conservatism by unifying a fractured conservative intellectual movement. ${ }^{176}$ And while current examinations of originalism's history emphasize connections between the theory, constitutional doctrine, and politics, G. Edward White and Dan Rodgers have tied originalism's emergence to much broader changes in America's relationship with the past. White has pointed out that history re-entered constitutional debates not just through originalism, but though critical and neo-republican interpretive approaches as well. It was not just Robert Bork, but also Duncan Kennedy and Akil Amar who turned towards history and away from political process theory. White attributes that development to the decline of broad based modernist assumptions that the past had no wisdom superior to contemporary social science. ${ }^{177}$ Rodgers sees a similar collapse in separation between the past and present in both originalism and post-modern social theory. ${ }^{178}$ Those broader intellectual changes and the opportunities they offered the advocates and opponents of originalism are crucial context for understanding the theory's development.

Combining that broader context with a productive dialogue between originalism's academic and political history can help produce a new, more accurate, and more useful history of originalism. But it is also true that the approach suggested here to the relationship of principle, politics, and

\footnotetext{
${ }^{175}$ Jack M. Balkin, The Framework Model and Constitutional Interpretation, in Philosophical Foundations of CONSTITUTIONAL LAW (Dyzenhaus \& Thorburn eds., forthcoming 2016) (manuscript at 9-10) (on file with author); Greene, How Constitutional Theory Matters, supra, note 10.

${ }^{176}$ Kersch, Ecumenicalism, supra note 71.

${ }^{177}$ White, Arrival of History, supra note 26.

${ }^{178}$ DANIEL T. RodGers, AGE OF Fracture (2011).
} 
motive is not limited to the analysis of originalism. Other legal theories can be seen as efforts to legitimate political action by manipulating terms with commonly understood meanings. So can moral and philosophical theories. So too can history. And recognizing that history can play this role may help explain why the debate over originalism's past is in its current state. Those skeptical of principle's role in originalism's history are also among the theory's most effective critics. ${ }^{179}$ And among those who argue principle was the driving force are some of the most effective advocates of originalism. ${ }^{180}$ Showing originalism's principled core legitimates the theory. Revealing it as camouflage for a controversial political agenda undermines it.

But just as politically motivated advocates of originalism could also be deeply concerned with constitutional principle, so too can scholars passionately concerned with the merits of originalism be simultaneously dedicated to the best traditions of scholarly debate. Motivated by the normative debate over originalism, and dedicated to the highest scholarly standards, the current divided history of originalism has raised important issues and provided powerful insights. As a result of it, we understand better the role of constitutional theory in politics, what progressives can learn from the right, and the differences between old and new originalism. But to understand the theory's current state and likely future, we need a new history of originalism that has moved past the artificial division between the theory's academic and political histories and past the motives that created it.

\footnotetext{
${ }^{179}$ See, e.g., Reva B. Siegel, Heller and Originalism's Dead Hand: In Theory and Practice, 56 UCLA L. REV. 1399 (2009).

${ }^{180}$ See, e.g., WhitTINGTON, CONSTITUTIONAL InTERPRETATION, supra note 4; Solum, Unwritten, supra note 4.
} 